\title{
Revisiting the feeding anatomy of the semi-aquatic lizard Dracaena guianensis Daudin, 1801 (Reptilia, Sauria) from the Western Brazilian Amazon
}

\author{
Antonio Tarlei de Souza Leite, ${ }^{1}$ Aline Nayara Poscai, ${ }^{2}$ André Luis da Silva Casas ${ }^{1,2}$ \\ ${ }^{1}$ Laboratório de Anatomia e Fisiologia Comparada (LAFCOM), Centro Multidisciplinar, Campus Floresta, Universidade Federal do Acre, Cruzeiro \\ do Sul, AC, Brazil \\ 'Laboratório de Pesquisa de Elasmobrânquios, Instituto de Biociências, Universidade Estadual Paulista “Júlio de Mesquita Filho", São Vicente, \\ SP, Brazil
}

Disclose and conflicts of interest: none to be declared by all authors

\begin{abstract}
Introduction: There are about 842 reptile species known in Brazil, including 799 Squamata, being the most diverse assemblage, comprising 72 amphisbaenians, 276 lizards, and 405 snakes. Lizards have adapted to different habitats with terrestrial, fossorial, arboreal, and semi-aquatic habits. These ecological differences are reflected in skull morphology, with structures that evolved following their dietary specificity. Teiid lizard Dracaena guianensis Daudin, 1801 inhabits swamps and spends most of its time on low trees, though feeding only occurs in water. Its feeding habits are different from other family members, and its diet is mostly composed of mollusks and crustaceans. Herein, the anatomy of feeding apparatus of $D$. guianensis population from the Western Brazilian Amazon was dissected and documented in four exemplars for the first time. As result, it presents a dorsoventrally compressed neurocranium, dorsally oriented orbits, and heterodont dentition. Those characteristics were different from the most family members, as observed in comparisons with Ameiva ameiva (Linnaeus, 1758), which presents lateral orbits, a cranium not compressed dorsoventrally, and homodont dentition. Furthermore, in $D$. guianensis, it was possible to verify that muscles related to food apprehension were extremely developed, such as adductors and hyolingual muscles, which increase bite force according to the force versus cutting area in cross section; while in $A$. ameiva the muscles presented smaller cross sectional area and consequently, less bite force. The correlation between the anatomy of feeding apparatus and stomach contents allowed a preliminary comparison of osteological and myological characteristics to its food habits, suggesting that heterodont condition was a selective pressure directly related to durophagy.

Keywords: Morphology; Myology; Osteology; Durophagy, Teiid.
\end{abstract}

\section{Introduction}

There are about 10,700 reptile species known worldwide. ${ }^{1}$ In Brazil they are widely distributed into 842 species and subspecies including six Crocodylia, 37 Testudines, and 799 Squamata, the latter being the most diverse assemblage, comprising 72 amphisbaenians, 276 lizards, and 405 snakes. ${ }^{1}$

Lizards have adapted to live in different habitats with terrestrial, fossorial, arboreal, and semi-aquatic habits, because of their richness in species diversity. ${ }^{2}$ These ecological differences are reflected in skull morphology, with complex systems formed by a variety of structural integrations that evolved following the form and functions related to their dietary specificity. ${ }^{3}$ Thus, the study of skull evolution allows a better understanding of how somatic and visceral skeleton elements were modified along the vertebrate evolutionary history. ${ }^{4}$

Teiid lizard Dracaena guianensis Daudin, 1801 (Fig. 1) inhabits swampy areas and spends most of its time on low trees, though feeding only occurs in water., Its feeding habits are different from other family members and lizards that moves on the ground, and its diet is mostly composed of shells of mollusks and crustaceans. ${ }^{5,7}$

This species presents molariform teeth associated with feeding on hard prey (durophagy), a condition found and shared with Paradracaena ${ }^{8}$, a fossil teiid that lived in similar habitats in Miocene (about 23 million years ago). ${ }^{9,8}$ This condition is absent in Ameiva ameiva (Linnaeus, 1758) for example, it hunts small insects in terrestrial environments and possesses homodont and sub-pleurodont dentition. ${ }^{10}$

From these differences, feeding mechanisms associated with diet are of great importance. For Herrel et al. ${ }^{11}$, herbivorous lizards possess relatively light skulls with less robust musculature and, consequently, minor potential for bite force, while bite power in omnivores indicates muscle strength and superior volume. Metzger and Herrel ${ }^{12}$ pointed out that mandibular muscular mass is used as an indicator of maximum force that can be applied on lizard's skull. Thus, anatomy represents specializations associated to feeding habits and related structures, which express 
a history of adaptations in each lizard species. ${ }^{5}$

Therefore, it is possible to verify that dietary habits of different teiid species resulted in specialized feeding structures, such as heterodont dentition for durophagy in D. guianensis. Thus, the present study aims to document the anatomy of cranial structures associated with durophagy in bones, teeth, and muscles of the feeding apparatus of a population of D. guianensis from streams and lakes of the Western Brazilian Amazon, and discuss these structures in a comparative context.
After these procedures, osteological parts and cranial muscles were documented through textual descriptions, illustrations, and digital photographs. Feeding behavior was documented in the field in two other D. guianensis.

For the comparisons with other teiid species, anatomical descriptions from A. ameiva, Salvator merianae, and the extinct Paradracaena sp., were accessed from the literature. . $^{10,15,16}$

The anatomical descriptions were based on the

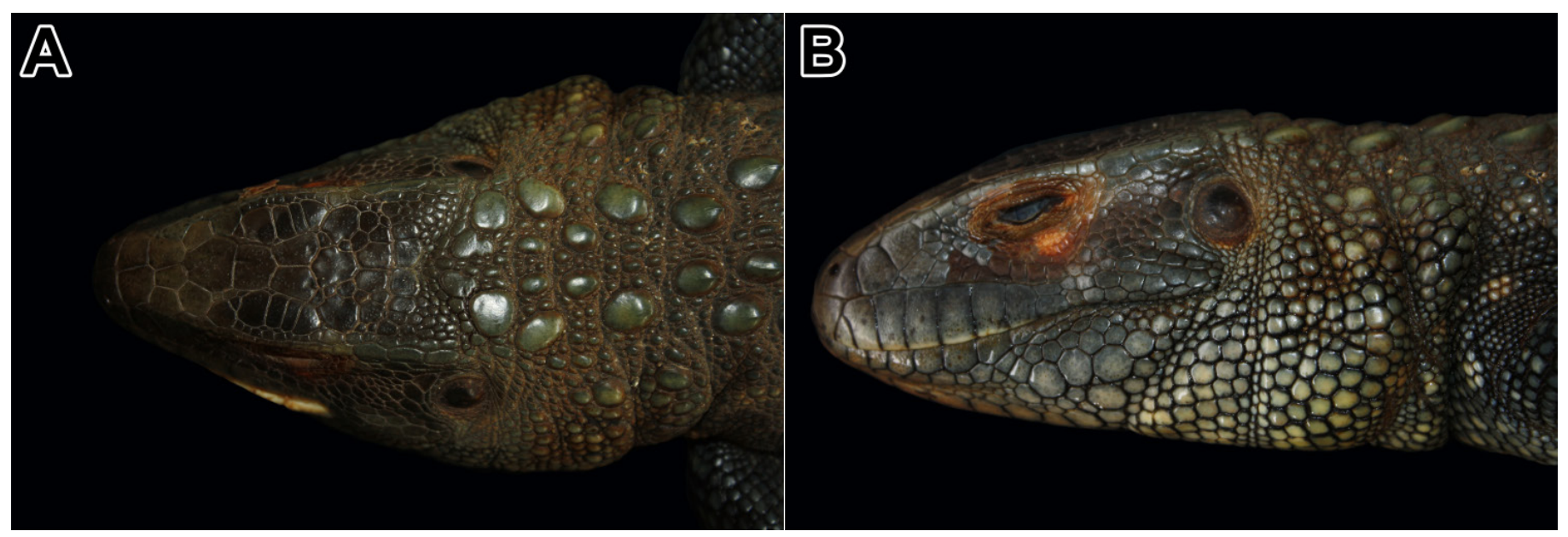

Figure 1. Exemplar of Dracaena guianensis (LAFCOM-014). A. dorsal view. B. lateral view.

\section{Material and methods}

The specimens of Dracaena guianensis were provided by the Laboratório de Anatomia e Fisiologia Comparada (LAFCOM) of the Federal University of Acre (UFAC). Two skeletons (LAFCOM-010 and 011) were examined after mechanical and biological cleaning (maceration), and chemical bleaching with hydrogen peroxide $10 \%$, a modified technique from Rodrigues, ${ }^{13}$ to document osteology and topography of skull bones related to their feeding habits. For comparative purposes, two specimens of Ameiva ameiva (LAFCOM-012 and 013) were stained $^{14}$ and examined.

Two other specimens of D. guianensis (LAFCOM-014 and 015) were collected after roadkill (collection license provided by the Sistema de Autorização e Informação em Biodiversidade (SISBIO), n. 48632-1). The specimens were fixed through intramuscular injections of $10 \%$ formalin solution and were stored in the same solution. Then transferred to $70 \%$ ethanol and later dissected, in order to show the head muscles.

Part of the digestive apparatus was removed and stomach contents was analyzed (LAFCOM-014), and stored in $70 \%$ ethanol solution. The head (LAFCOM-015) was dissected from the superficial tissues to the skull, and then subjected to the necrophagous coleopteran Dermestes maculatus De Geer, 1774 to clean muscles fibers, and to expose the articulated bones, conserving its topography. following references: Estes and Williams ${ }^{17}$ and Hsou et $a .^{16}$ for teeth nomenclature, Romer ${ }^{3}$ for osteology, and Herrel et al. ${ }^{18}$ for myology.

This study had the allowance of the Comitê de Ética no Uso de Animais (CEUA) from the Federal University of Acre through CEUA-86/2015, and also had the approval from SISBIO n. 48632-1.

\section{Results}

Dracaena guianensis has a large elongated head and a flat orbital region with anatomical structures that are homologous to A. ameiva. The main difference in relation to other family members is the dorsoventral flattening of the skull, in which orbits are dorsally positioned and the jaws are curved possessing heterodont dentition (Fig. 2 and 3): rostral (unicuspid teeth) being small and sharp; caudal (molariform teeth), crown circular to suboval with no striations, and sub-pleurodont teeth implantation (Fig. 2).

\section{Jaw adductor muscles}

Muscles presented up to four muscular venters. Dorsally, it is possible to recognize one of its parts as the temporal muscle that originates in the inner margins of temporal opening. Part of temporal muscle venter fills the temporal cavity, entering into coronoid process. In medial view of the articular bone, there are two insertions of the temporal muscle (Figs. 4A, 4B, $4 \mathrm{C}, 5 \mathrm{~A})$. 


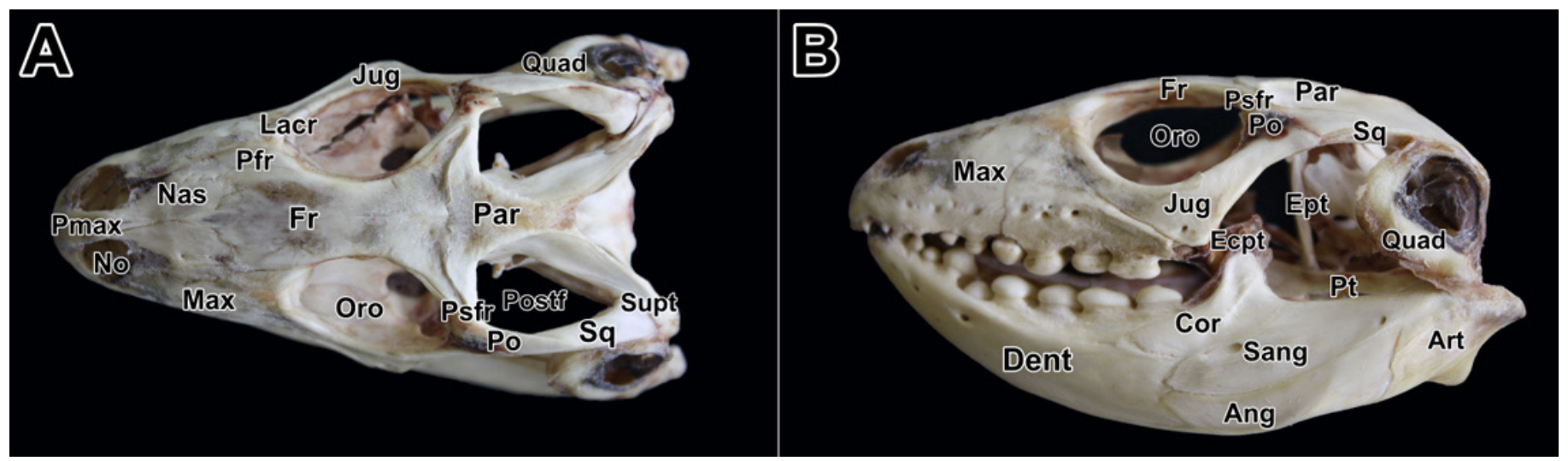

Figure 2. Skull bones. A. Dorsal view. B. Lateral view. Pmax. Pre-maxillary. Max. Maxilla. Nas. Nasal. No. Nasal opening. Pfr. Prefrontal. Fr. Frontal. Lacr. Lacrimal. Jug. Jugal. Oro. Orbital opening. Par. Parietal. Psfr. Postfrontal. Po. Postorbital. Sq. Squamosal. Supt. Supratemporal. Quad. Quadrate. Ept. Epipterygoid. Pt. Pterygoid. Cor. Coronoid. Sang. Supra-angular. Ang. Angular. Art. Articular. Dent. Dentary. Postf. Post-temporal foramen.

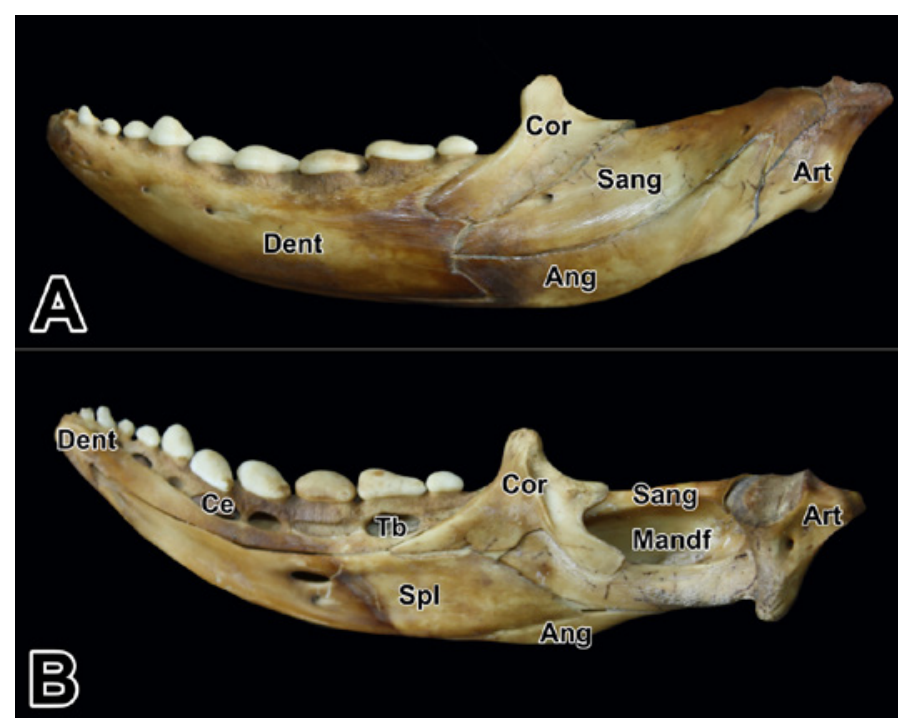

Figure 3. Jaw of Dracaena guianensis. A. Labial view. B. Lingual view. Dent. Dentary. Ang. Angular. Sang. Supra-angular. Cor. Coronoid. Art. Articular. Spl. Splenial. Mandf. Mandibular foramen. Ce. Cementum. Tb. Tooth base.

Superficial venter of temporalis muscle originates rostrally into postorbital and squamosal bones, and caudally into quadrate bone. Its insertion was observed in supra-angular and angular bones, in which extends cranially to dentary bone (Figs. 4B, 4C, 5B).

Jaw depressor muscle originates in squamosal, supratemporal, parietal, and quadrate bones articulation, and it is inserted in the articular bone (Figs. 4A, 4B, 4C, 5B).

Pterygoid muscle originates in the dorsolateral region of the articular bone, possessing two insertions, as follows: (1) pterygoid and (2) aponeurosis insertion into articular, angular, supra-angular and pterygoid bones, medially (Fig. 4B).

\section{Intermandibular muscle}

This muscle divides into two parts: rostral intermandibularis and caudal intermandibularis. The first originates in the articulation region between quadrate and articular bones. Muscular fibers are directed medially and are inserted in ventral median raphe in cervical region (Fig. 4B). Caudal intermandibularis muscle originates in the ventral view of dentary, which are inserted in the same contralateral structure. Its fibers are arranged parallel to each other.

\section{Hyolingual muscles \\ Neck constrictor muscle}

It originates in the median line of linea alba, being associated with cervical and suprascapular muscles. It is inserted into a thin layer of connective tissue with omohyoid and sternocleidomastoid muscles.

\section{Omohyoid muscle}

It is located medially to neck constrictor muscle. It enters in ventral median raphe, caudally to mandibular hyoid muscle.

\section{Mandibular hyoid muscle}

It originates on quadrate and articular bones articulation, medially to pterygoid muscle. It inserts in the ventral median raphe caudally to intermandibularis caudal muscle.

\section{Gastrointestinal tract}

The esophagus and stomach mucosa has an extensive muscular layer. Gastric secretion was observed in the cardiac region with an extensive area of secretory mucosa, and an extensive layer of smooth musculature.

In the terminal part of the stomach, there was a body dilatation in which were found two opercula of gastropods. In the pyloric region, there was a decrease in the circumference of the alimentary canal when compared to other portions of the stomach, and duodenum presents a smaller lumen in relation to the cranial portion of gastrointestinal tract.

In small intestine was observed loops in jejunal and ilium. A rudimentary caecum was associated with colon. Through an incision in small intestine, it was possible to verify a large amount of villi in the duodenum mucosa when compared to other parts. The large intestine is formed by cecum, colon, and rectum. While it was examined, the presence of feces was verified (Fig. 6). 


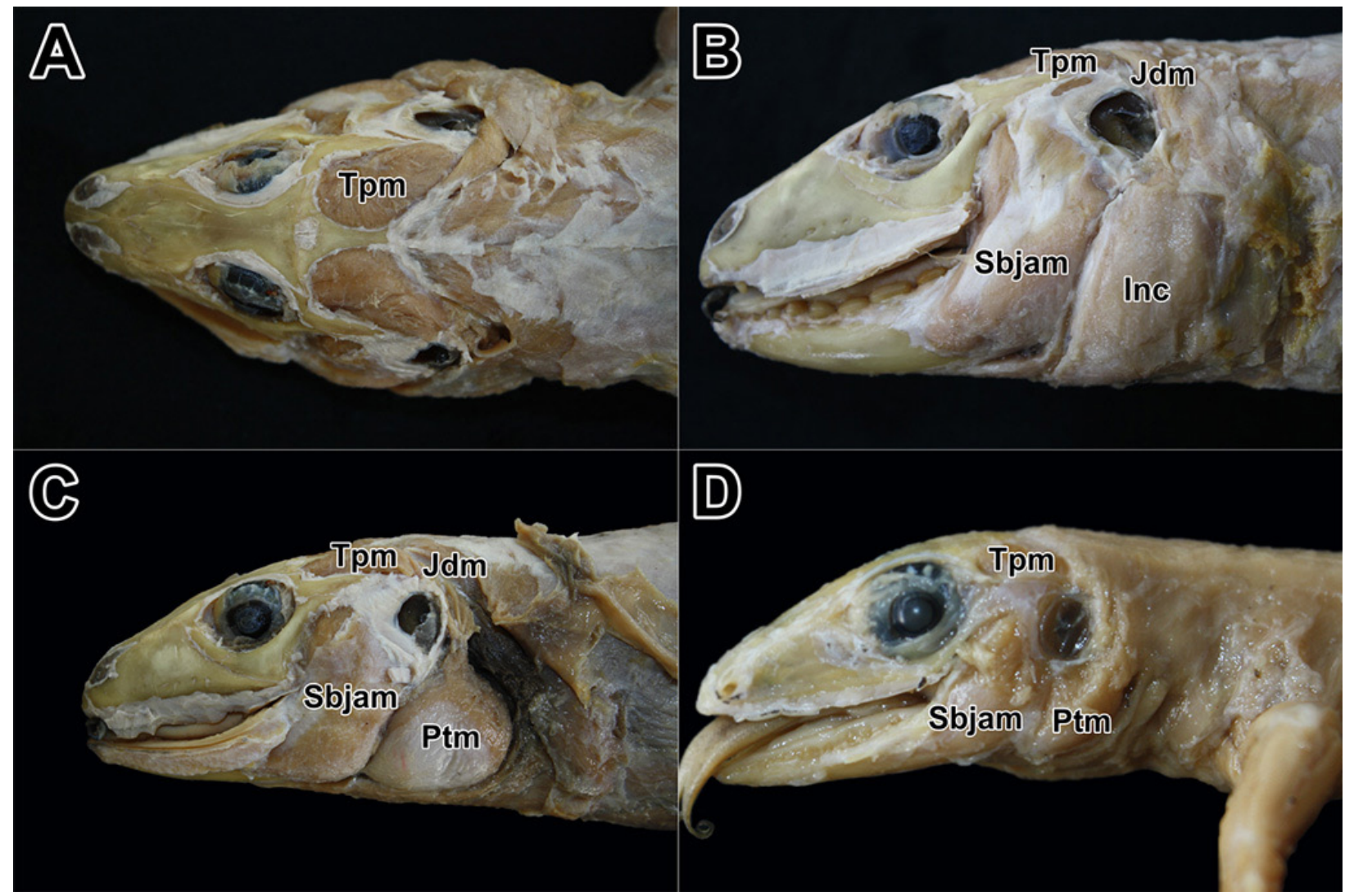

Figure 4. Head muscles of Dracaena guianensis. A. Dorsal view. B. C. Lateral view and A. ameiva. D. Lateral view. Tpm. Temporal muscle. Jdm. Jaw depressor muscle. Sbjam. Superficial belly of jaw adductor muscle. Ptm. Pterygoid muscle. Inc. Intermandibular caudal muscle.
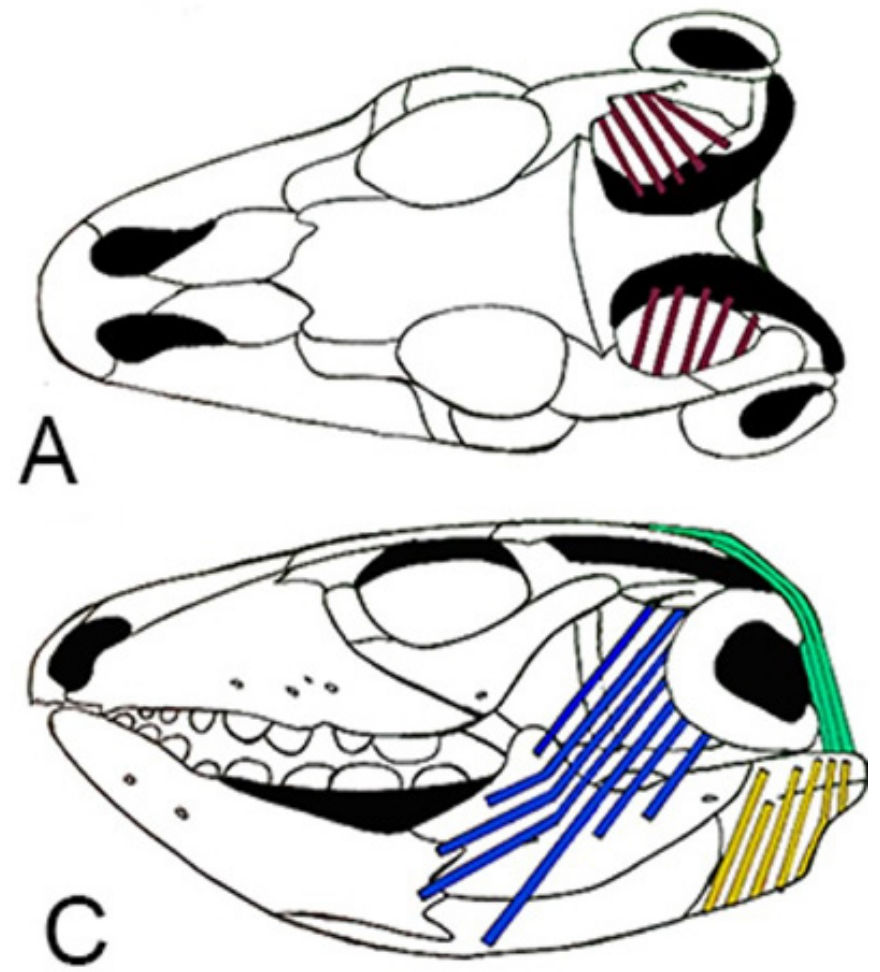

Figure 5. A. B. Lines indicate the arrangement of muscle fibers between their origin and insertion. Tpm. Red lines temporal muscle. Jdm. Green lines Jaw depressor muscle. Sbjam. Blue, superficial venter of jaw adductor muscle. Ptm. Yellow, pterygoid muscle.

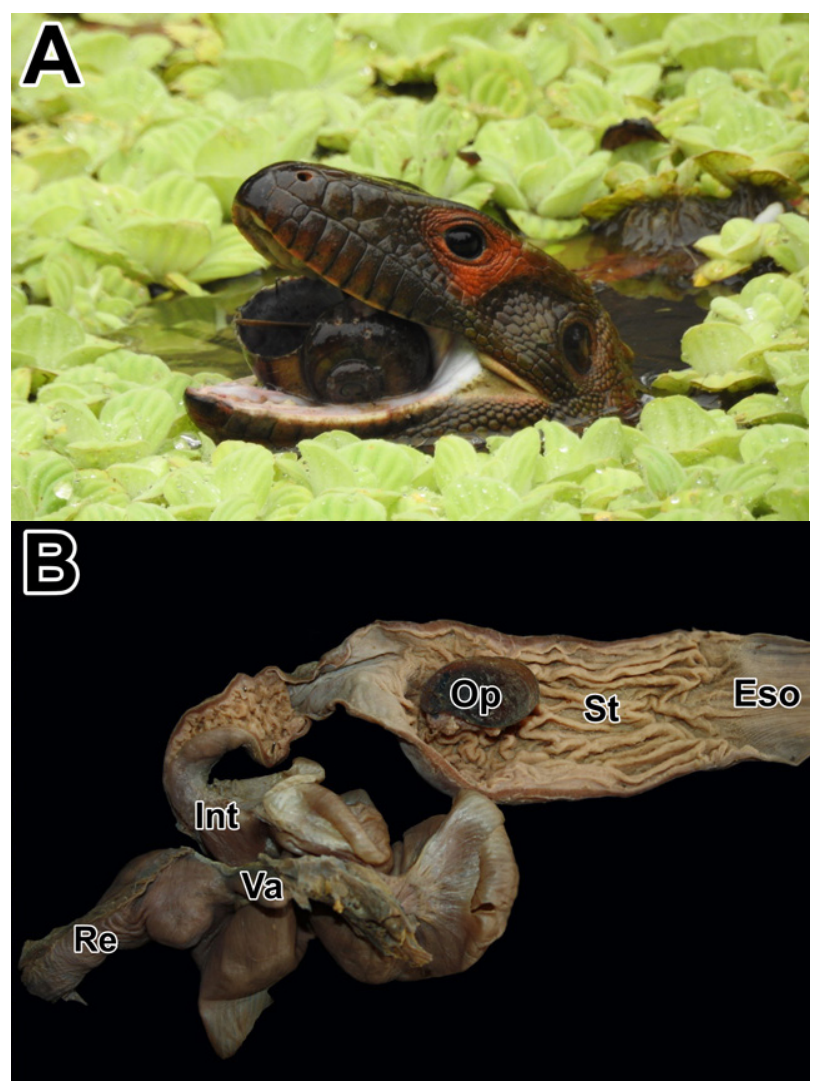

Figure 6. A. Dracaena guianensis feeding on a Pomacea spp in Igarapé Crôa, Cruzeiro do Sul, Acre, January, 2018, photo credit: Paulo Sérgio Bernarde. B. Digestive tract of D. guianensis. Eso. Esophagus. St. Stomach. Int. Intestine. Va. Vermiform appendix. Re. Rectum. Op. Opercula of gastropods. 


\section{Discussion}

Skull is of great importance to protect brain, sensory systems, and to support structures that are fundamental to catching and seizing food, which leads to competition for space ${ }^{19}$ associated with habitat conditions. Therefore, feeding habits influence skull shape, a result from the association between ecology and anatomy of the species. ${ }^{5}$

In the present study, it was observed that D. guianensis employs a durophagous feeding strategy with a skull adapted to resist to pressures exerted by jaw musculature (Figs. 2, 4A, 4B, 4C). Among these structures are the flattened neurocranium, dorsally inclined orbits (evidencing semi-aquatic habits), and loss of the quadrate bone joint with jugal bone. The last, a shared condition with Rhynchocephalia and Squamata, which allowed greater insertion into the jaw adductor musculature that influences chewing, being an evolutionary tendency in lizards that require larger muscles for their feeding as observed by Rieppel and Gronowski. ${ }^{20}$

The different shapes and sizes of teeth were distributed in the dorsal margins of the lower and upper jaws. Lower jaw bases were filled with cement, and dentition was characterized as sub-pleurodont with heterodonty ${ }^{8,16}$ (Figs. 2B, 3B), being those specializations related to durophagy, a different condition described in literature in relation to the family pattern..$^{8,16}$

These modifications of the skull correspond to their diet and way of life. When comparing these structures with other teiids, it is possible to distinguish significant differences. For example, A. ameiva lizards present acute, elongated lower jaw ${ }^{21}$ with a mandibular cavity between the supra-angular and angular bones, ${ }^{15}$ place of adductor muscles insertion. Dentition of this species is homodont and contains sub-pleurodont teeth ${ }^{10}$ inserted in the lateral margins of the jaws. All of those characteristics differ from D. guianensis. Noteworthily, most of the differences between these species are found in the jaws and in the dorsoventral flattening of the skull, reflecting the different feeding habits, being respectively durophagy in D. guianensis, and insectivory in A. ameiva.

Still, it is possible to observe significant differences in the adductor muscles between these species. Such modifications are correlated to a network of adductor muscles that, in smaller lizards such as A. ameiva, in which express a small force in the bite. It is related to feeding efficiency and breadth of the diet along the functional axes, i.e. size of the prey and its level of hardness. ${ }^{22,}{ }^{23}$ Dracaena guianensis possess robust muscles, such as jaw adductors, especially the pterygoid, that possess two muscle venters, being the largest muscle related to chewing (Figs. 4A, 4B). According to Metzger and Herrel, ${ }^{12}$ it may indicate a high potential force that could be related to muscular fiber arrangement. This condition was not observed in insectivorous A. ameiva (Fig. 4D).

Thus, heterodonty is an important adaptive characteristic to durophagy, which was also described in extinct Paradracaena that lived in a similar habitat to its extant relative, D. guianensis. ${ }^{24}$ According to Sullivan and Estes ${ }^{9}$ and Nydam and Cifelli ${ }^{25}$, Paradracaena also possessed pseudo-thecodont dentition and dentary with an accentuated curvature. Such characteristics are shared with D. guianensis which possess dentary implants and sub-pleurodont condition ${ }^{8,16}$ (Figs 2B, 3B).

Although presumably D. guianensis employ a similar feeding strategy for hardness ${ }^{24}$, it was possible to identify differences in the number of teeth. According to Sullivan and Estes ${ }^{9}$, Paradracaena possessed 15 teeth, while D. guianensis had 10 to 11 teeth. In the present study, it was possible to observe the presence of 10 to 12 teeth in D. guianensis, differing from the standard established in literature. This condition was observed in individuals of different sizes suggesting that there may be an ontogenetic variation in the number of teeth in this species.

Synapomorphies mentioned above between D. guianensis and Paradracaena sp. suggest a close phylogenetic relationship. . $6,27,28,17,29,8$ It showed that an important adaptive value for them was their feeding, which promoted significant changes in skull anatomy. ${ }^{30}$, ${ }^{31}$ These findings in the present study reinforce this hypothesis as when examining stomach contents of $D$. guianensis from Western Brazilian Amazon, in which were found gastropod opercula, without any vestiges of the shells (Fig. 6B). This information indicates that during its feeding, this species is able to crush the shells (Fig.6A), and swallow soft contents, confirming the adaptations of the skull for durophagy.

Results in the present study corroborated with the findings of Schaerlaeken et al. ${ }^{32}$, in which compared D. guianensis skull morphology, bite force, and kinematics associated with feeding with the omnivorous Salvator merianae (Duméril \& Birbon, 1839), a hypothesized sister group of the genus Dracaena. ${ }^{33}$ Despite phylogenetic proximities between the species, Schaerlaeken et al. ${ }^{32}$ used sophisticated techniques to evaluate and describe some structures and functions of the species skulls, such as Computed Tomography (CT) scan analyses associated with feeding behavior and habits in captive exemplars, to identify differences between those taxa. They also established that D. guianensis presents muscular and bone adaptations for durophagy.

Even with different approaches performed here, comparisons between the insectivore A. ameiva and D. guianensis from an unknown Amazonian population, through gross anatomy technics, achieved the similar results of Schaerlaeken et al. ${ }^{32}$ The different taxa were compared and remarkable differences in skull anatomy and musculature related to feeding strategies were observed, such as durophagy in D. guianensis. 


\section{Conclusion}

The populations of Dracaena guianensis from streams and lakes of the Western Brazilian Amazon possessed structural modifications in the skull when compared to other teiids, such as flattened neurocranium, dorsally inclined orbits, concave shaped lower jaw, teeth with different shapes and sizes, and heterodont dentition. Those characteristics are directly related to durophagous feeding habits. In addition, it was possible to document variations in the number of teeth of the specimens examined in relation to the standard described in literature for this species. This variation should be examined in a phylogenetic context in future studies.

Adductor muscle complex has four muscle venters that possibly provide an increase in strength in bite mechanism in relation to other teiids, as cited by Herrel et al. ${ }^{11}$ Herbivorous lizards possess relatively light skulls with less robust musculature and, consequently, minor potential for bite force, while bite power in omnivores indicates muscle strength and superior volume. Thus, heterodonty and other structural modifications of the skull is related to feeding strategy, and associated with durophagy and to semi-aquatic habits of this species.

\section{Acknowledgments}

We would like to thank CNPq for support this study. We also would like to thank the program PIBIC/CNPq contract 004/2015 that granted to the first author a scientific initiation scholarship. Furthermore, we are very grateful for all comments, suggestions, and support from Dr. Francisco Ricardo Negri, Dr. Reginaldo Assêncio Machado from UFAC Campus Floresta, and to Connor Neagle for the English review. We specially thank Dr. Paulo Sérgio Bernarde from UFAC Campus Floresta who documented in photos and videos Dracaena guianensis feeding habits in natural habitat in Igarapé Crôa, Acre State, and the allowance to use this valuable material in the present research.

\section{References}

1. COSTA, H, C; BÉRNILS, R, S. Répteis do Brasil e suas Unidades Federativas: Lista de espécies. Herpetologia Brasileira 2018; 8: 1-10. 2. BERNARDE, P, S. Anfíbios e Répteis: introdução ao estudo da herpetofauna brasileira. Anolis Books; 2012.

3. ROMER, S, A. Osteology of the reptiles. Chicago: University of Chicago Press; 1956.

4. HÖFLING, E. Chordata: manual para um curso prático. São Paulo: Edusp; 1995.

5. VANZOLINI, P, E; VALENCIA J. The genus Dracaena, with a brief consideration of macroteiid relationships (Sauria, Teidae). Arquivos de Zoologia 1965; 13: 7-35.

6. MASSARY, J, C; HOOGMOED, M, S; BLANE, M. Comments on the type specimen of Dracaena guianensis Daudin, 1801 (Repitilia: Sauria: Teiidae), and rediscovery of species in French Guiana. Zool. Med. Leiden 2000; 14: 167-180.

7. MESQUITA, D, O; COLLI, G, R; COSTA, G, C; FRANÇA, F, G, R; GARDA, A, A; PÉRES JR. A, K. At the Water's Edge: Ecology of Semiaquatic Teiids in Brazilian Amazon. Journal of Herpetology 2006; 40: 221-229.

8. PUJOS, F; ALBINO, A, M; BABY, P; GUYOT, J, L. Presence of the extinct lizard Paradracaena (Teiidae) in the Middle Miocene of the Peruvian Amazon. Journal of Vertebrate Paleontology 2009; 29: 594-598.

9. SULLIVAN, R, M; ESTES, R. A reassessment of the fossil Tupinambinae. In: R.F. Kay; R.H. Madden; R.L. Cifelli \& J.J. Flynn (eds.) Vertebrate paleontology in the neotropics - the Miocene fauna of La Venta; Colombia: Smithsonian Institution Press; 1997: 100-112.

10. PRESCH, W. A survey of the dentition of the macroteiid lizards (Teiidae: Lacertilia). Herpetologica 1974; 344-349.

11. HERREL, A; VANHOOYDONCK, B; VAN DAMME R. Omnivory in lacertid lizards: adaptive evolution or constraint. Journal of evolutionary biology 2004; 974-984.

12. METZGER, K, A; HERREL A. Correlations between lizard cranial shape and diet: a quantitative, phylogenetically informed analysis. Biological Journal of the Linnean Society 2005; 433-466.

13. RODRIGUES, H. Técnicas Anatômicas. Vitória, ES: Arte Visual; 1998. 14. TAYLOR, W, R; VAN DYKE, G, C. Revised procedures for staining and clearing small fishes and other vertebrates for bone and cartilage study. Cybium 1985; 09: 107-119.

15. TEDESCO, M, E; KRAUSE, L; ALVAREZ, B, B. Descripción del sincráneo de Ameiva ameiva (Linnaeus) (Squamata, Teiidae). Revista Brasileira de Zoologia 1999; 16: 1025-1044.

16. HSIOU, A, S; SCHUBERT, B, W; WINCK, G; ONARY-ALVES, S, Y; AVILLA, L, S. New Quaternary Teiid (Lepidosauria, Squamata) Lizard Remains
From Gruta do Urso. Rev. Bras. Paleontol 2016; 19: 233-242.

17. ESTES, R; WILLIAMS, E, E. Ontogenetic variation in the molariform teeth of lizards. Journal of Vertebrate Paleontology 1984; 96-107.

18. HERREL, A; CANBEK, M; OZELMAS, U; UYANOGLU, M; KARAKAYA, M. Comparative Functional Analysis of the Hyolingual Anatomy in Lacertid Lizards. The Anatomical Record 2005; 561-573.

19. BAREL, C, D, N. Towards a constructional morphology of cichlid fishes (Teleostei, Perciformes). Netherlands Journal of Zoology 1982; 357-424.

20. RIEPPEL, O; GRONOWSKI, R. W. The loss of the lower temporal arcade in diapsid reptiles. Zoological Journal of Linnean Society 1981; 72: 203-217.

21. SKINNER, M, M. Ontogeny and adult morphology of the skull of South African skink, Mabuya capenses (Gray). Ann. Univ Stellenbosch 1973; 48: 1-116.

22. VERWAIJEN. Relationships between head size, bite force, prey handling efficienc and diet in two sympatric lacertid lizards. Functional Ecology 2002; 16: 842-850.

23. HERREL, A; JOACHIM, R; VANHOOYDONCK, B; IRSCHICK, D. Ecological consequences of ontogenetic changes in head shape and bite performance in the Jamaican lizard Anolis lineatopus. Biological Journal of the Linnean Society 2006; 89: 443-454.

24. KRAUSE, L. Fossil record of the family Teiidae. Notes on paleobiogeography, current distribution, and habits of the macroteiids. (Sauria, Scincomorpha, Teiidae). Studies on Neotropical Fauna and Environment 1985; 175-188.

25. NYDAM, R, L; CIFELLI, R, L. A new teiid lizard from the Cedar Mountain Formation (Albian-Cenomanian boundary) of Utah. Journal of Vertebrate Paleontology 2002; 276-285.

26. ESTES, R. Miocene lizards from Colombia, South America. Museum of Comparative Zoology; 1961.

27. ESTES, R. Sauria terrestria, Amphisbaenia, Handbuch der Palaoherpetologie. New York: G. Fischer Verlag; 1983.

28. DALRYMPLE, G, H. On the jaw mechanism of the snail-crushing lizards, Dracaena Daudin 1802 (Reptilia, Lacertilia, Teiidae). Journal of Herpetology 1979; 303-311.

29. NYDAM, R, L; EATON, J, G; SANKEY, J. New taxa of transverselytoothed lizards (Squamata: Scincomorpha) and new information on the evolutionary history of "teiids". Journal of Paleontology 2007; 538-549.

30. HERREL, A; SCHAERLAEKEN, V; MEYERS, J, J; METZGER, K, A; ROSS, $C, F$. The evolution of cranial design and performance in squamates: 
Consequences of skull-bone reduction on feeding behavior. Integrative and Comparative Biology 2007; 47: 107-117.

31. HERREL, A; HOLANOVA, V. Cranial morphology and bite force in Chamaeleolis lizards adaptations to molluscivory. Zoology 2008; 467475.

32. SCHAERLAEKEN, V; HOLANOVA, V; BOISTEL, R; AERTS, P; VELENSKY,
P; REHAK, I; ANDRADE, D; HERREL, A. Built to Bite: Feeding Kinematics, Bite Forces, and Head Shape of a Specialized Durophagous Lizard, Dracaena guianensis (Teiidae). J. Exp. Zool 2012; 317: 371-381.

33. GIUGLIANO, L, G; COLLEVATTI, R, G; COLLI, G, R. Molecular dating and phylogenetic relationships among Teiidae (Squamata) inferred by molecular and morphological data. Mol Phyl Evol 2007; 45:168-179.
Received: November 06, 2019

Accepted: January 12, 2020
Corresponding author André Luis da Silva Casas andrecasas.ufac@gmail.com 